\title{
A Standard Framework for Effective Progress Reports in the State of Kuwait
}

\author{
Moustafa Kotb1, Mohamed Ibrahim Abdel Razik², Yousef S. Alolayan ${ }^{3}$ \\ ${ }^{1}$ Structural Department, Faculty of Engineering, Al-Azhar University, Cairo, Egypt \\ ${ }^{2}$ Reinforcement Concrete Department, Al-Azhar University, Cairo, Egypt \\ ${ }^{3}$ Faculty of Engineering, Al-Azhar University, Cairo, Egypt \\ Email: icpm_ku@yahoo.com
}

How to cite this paper: Kotb, M., Razik, M.I.A. and Alolayan, Y.S. (2018) A Standard Framework for Effective Progress Reports in the State of Kuwait. American Journal of Operations Research, 8, 42-49. https://doi.org/10.4236/ajor.2018.81004

Received: January 12, 2018

Accepted: January 23, 2018

Published: January 26, 2018

Copyright (๑) 2018 by authors and Scientific Research Publishing Inc. This work is licensed under the Creative Commons Attribution International License (CC BY 4.0).

http://creativecommons.org/licenses/by/4.0/

\begin{abstract}
The construction industry in the State of Kuwait has recently witnessed a rapid growth as the volume of construction projects increased significantly over the past decade. Because of the progress and growth of the industry and the size of the projects, the volume of disputes between the parties to the various contracts has increased accordingly. As projects become larger and more complex, their management and control become more difficult, especially in the absence of effective standard systems to for managing project progress and determining the delay, if any. Even the simple issues, as well as the large ones, if neglected and unaddressed in a timely manner, can cause huge problems that concerns to all project parties. Irrespective of addressing and managing construction delays legally, the resulting legal disputes always have other negative effects on the contracting parties. If the parties to the contract have an insight that enables them to forecast and identify the issues that may cause a conflict before it occurs, that eliminates a myriad of problems before they occur, and greatly reduces the chances of further conflict between contracting parties. This paper presents a framework for a novel progress reporting system that can help minimize contract disputes in the state of Kuwait.
\end{abstract}

\section{Keywords}

Construction, Progress Reports, Contract Disputes, Contractor Selection, Project Control

\section{Introduction}

The methods for project cost and schedule performance monitoring have been largely explored. Yet, besides the attempts to get to standard practices, construc- 
tion projects, in particular, involve tailored methods for decomposing the complex scope of work into work items and tasks with regard to cost and schedule. A proper work breakdown structure serves as a basis for progress measurement and reporting [1].

With the aid of a comprehensive work breakdown structure, efficient progress control is needed to complete project on time and according to the required quality. However, neither typical cost nor quantity monitoring are suitable for this purpose. The weak link of detailed progress monitoring and control is the manual data collection, which is time consuming and labor intensive. Moreover, manual data collection is not only expensive, but also error prone. Existing project management software package, such as Primavera, have simple modules with bidirectional links to hand-held devices for site data collection, but even they require that the data be collected manually from daily progress reports [2].

In a recent research study, Navon and Haskaya [2] pointed out that construction project recording systems should normally hold vast amounts of data, such as number of workers broken down to trades; materials arriving to the site; number and type of equipment; receipt of drawings and plans; weather conditions; contractors or subcontractors; work accomplished; major events (e.g. concrete pouring); problems, etc. All these data are logged on a daily basis, which means that they are very detailed and up to date. Additionally, as opposed to the manual alternative, these data are accurate and reliable, as they are legally signed by representatives of the owner and the contractor. Unfortunately, such a valuable source of reliable and detailed data is not normally used for the management and control of the ongoing project; it is mainly used for litigation regarding claims and other disputes.

Additionally, written progress reports have their limitations because their quality and clarity depend on the writing skills of the writer and often they are incomplete. As a result, many important details are left out, or lost, and they can never be recovered. This is because, in many cases, the handwritten document is illegible and search possibilities are either limited, or labor intensive.

Because of all the above, even the litigation purposes are sometimes only partially achieved. Navon and Haskaya [2] presented a computerized Daily Site Report, which serves as a data collection tool for progress monitoring. The data are collected anyhow, without any connection to the progress monitoring needs, and hence the cost of collecting them is negligible. The prototype and the case study project demonstrate the potential of such a tool for real time progress monitoring.

This research examines the characteristics of progress reporting in contracts performed in accordance with the traditional systems currently in use in Kuwait. The research also investigates and highlights the effectiveness of the traditional systems in limiting construction disputes and litigation. The dispute between the parties has long been part of the industry, with the vast majority of project conflict issues related to the problems of time delay and its financial implications. As 
it is clear from the large number of disputes in front of Kuwaiti courts and arbitral tribunals, this reflects the inability to identify and address the time and financial deviations of the contract in a timely manner during the implementation phase.

\section{Research Objectives}

This study aims to give the project stakeholders the possibility of identifying problems as they occur and taking the immediate measures necessary to stop the aggravation of these problems by using standard progress report. The question is Did we need it or not? Using surveys for different parties, the answer will appear by using the next methodology, we will reach the two main objectives;

1) Progress report importance.

2) Characteristics of suggested progress report.

\section{Research Methodology}

The research methodology consists of three main steps:

A. Observation

B. Data Collection

C. Data Analysis \& Results

We are going to use questionnaire procedures in order to observe the market needs for the different constriction industrial parties.

These parties are public owners, private owners, CM Consultants, Design Consultants \& Contracts (public, private).

\section{Requirement for Effective Progress Report in Construction Industry}

\subsection{Observation}

It is clear from the large number of disputes in front of the courts and arbitral tribunals, that the parties to the contract are unable to identify and address the time and financial deviations of the contract, in a timely manner during the implementation phase due to the poor management of the project and the loss of the parameters of the conflict. We also discovered that next element could be major reasons for the previous states

- Lack of good archiving of documents.

- The facts of the dispute are not substantiated.

- Failure to address the problem in a timely manner and take the appropriate action, which missed the opportunity to avoid that conflict in time and before the aggravation by taking the necessary action in a timely manner.

\subsection{Data Collection}

A questionnaire was prepared from 100 citizens and residents of Kuwait in their various forms of this type of industry, which are related to various projects, which are mostly construction projects or real estate investment projects. The 
different forms of their relationship with these projects give an objective picture of the need for this search. This sample (Figure 1) included the following:

- 25 employees of senior management in government bodies as representatives of employers.

- 15 employees of private sector companies as representatives of employers.

- 15 employees in the administrative bodies as representatives of project management.

- 15 workers in the role and consulting offices.

- 30 senior management personnel of local and international contracting companies in the Gulf region in general and Kuwait in particular.

\section{The selected sample was asked the following questions:}

Q1. Can contracting parties know the status of a project without progress reports?

The response for Q1 can be summarized in the following table.

\begin{tabular}{cccc}
\hline Sample & Don't Know & No & Yes \\
\hline Public Owners & 1 & 24 & 0 \\
Private Owners & 4 & 11 & 0 \\
PM firms & 0 & 15 & 0 \\
Engineering firms & 0 & 15 & 0 \\
Contractors & 3 & 26 & 1 \\
Total & $\mathbf{8}$ & $\mathbf{9 1}$ & $\mathbf{1}$ \\
\hline
\end{tabular}

Q2. Is there a specific and effective system to monitor projects?

The response for Q2 can be summarized in the following table.

\begin{tabular}{cccc}
\hline Sample & Don't Know & No & Yes \\
\hline Public Owners & 3 & 19 & 3 \\
Private Owners & 8 & 5 & 2 \\
PM firms & 0 & 0 & 15 \\
Engineering firms & 5 & 4 & 6 \\
Contractors & 8 & 13 & 9 \\
Total & $\mathbf{2 4}$ & $\mathbf{4 1}$ & $\mathbf{3 5}$ \\
\hline
\end{tabular}

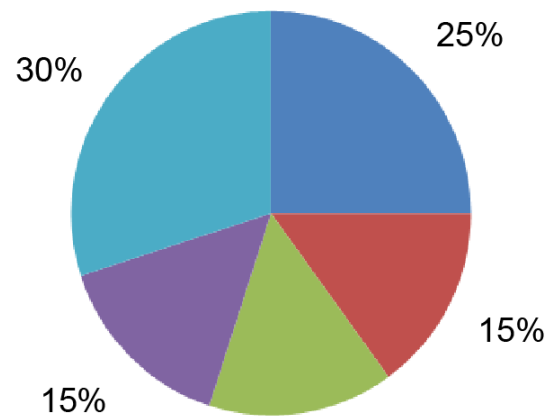

$15 \%$
Public Owners

Private Owners

Construction Management Consultants

Design Consultants

Contractors

(Public/Private)

Figure 1. Study participants by project role. 
Q3. How do you evaluate the benefits of periodic progress reports prepared by any of the parties to the contract?

The response for Q3 can be summarized in the following table.

\begin{tabular}{ccccccc}
\hline Sample & Don't Know & None & Weak & Good & Very Good & Exclnt. \\
\hline Public Owners & 0 & 1 & 8 & 14 & 2 & 0 \\
Private Owners & 0 & 2 & 10 & 2 & 1 & 0 \\
PM firms & 0 & 0 & 2 & 8 & 5 & 0 \\
Engineering firms & 0 & 1 & 7 & 6 & 1 & 0 \\
Contractors & 0 & 5 & 15 & 10 & 0 & 0 \\
Total & $\mathbf{0}$ & $\mathbf{9}$ & $\mathbf{4 2}$ & $\mathbf{4 0}$ & $\mathbf{9}$ & $\mathbf{0}$
\end{tabular}

Q4. How do progress reports help in alerting owners against possible future claims and preparations for adequate response?

The response for Q4 can be summarized in the following table.

\begin{tabular}{ccccccc}
\hline Sample & Don't Know & None & Weak & Good & Very Good & Exclnt. \\
\hline Public Owners & 0 & 2 & 15 & 7 & 1 & 0 \\
Private Owners & 0 & 7 & 4 & 3 & 1 & 0 \\
PM firms & 0 & 0 & 4 & 10 & 1 & 0 \\
Engineering firms & 0 & 4 & 6 & 4 & 1 & 0 \\
Contractors & 0 & 6 & 19 & 5 & 0 & 0 \\
Total & $\mathbf{0}$ & $\mathbf{1 9}$ & $\mathbf{4 8}$ & $\mathbf{2 9}$ & $\mathbf{4}$ & $\mathbf{0}$ \\
\hline
\end{tabular}

Q5. How do you evaluate the accuracy of the Reported Project Percent Complete of progress reports in comparison to the Actual Project Percent Complete?

The response for Q5 can be summarized in the following table.

\begin{tabular}{ccccccc}
\hline Sample & Don't Know & None & Weak & Good & Very Good & Exclnt. \\
\hline Public Owners & 0 & 0 & 18 & 6 & 1 & 0 \\
Private Owners & 1 & 0 & 11 & 2 & 1 & 0 \\
PM firms & 0 & 0 & 4 & 9 & 2 & 0 \\
Engineering firms & 1 & 0 & 8 & 5 & 1 & 0 \\
Contractors & 0 & 2 & 24 & 4 & 0 & 0 \\
Total & $\mathbf{2}$ & $\mathbf{2}$ & $\mathbf{6 5}$ & $\mathbf{2 6}$ & $\mathbf{5}$ & $\mathbf{0}$
\end{tabular}

Q6. How do you evaluate the impact of progress reports in limiting problems and disputes among the contracting parties?

The response for Q6 can be summarized in the following table.

\begin{tabular}{ccccccc}
\hline Sample & Don't Know & None & Weak & Good & Very Good & Exclnt. \\
\hline Public Owners & 0 & 2 & 16 & 6 & 1 & 0 \\
Private Owners & 0 & 6 & 6 & 2 & 1 & 0 \\
PM firms & 0 & 2 & 6 & 5 & 2 & 0 \\
Engineering firms & 0 & 6 & 7 & 1 & 1 & 0 \\
Contractors & 0 & 5 & 20 & 5 & 0 & 0 \\
Total & $\mathbf{0}$ & $\mathbf{2 1}$ & $\mathbf{5 5}$ & $\mathbf{1 9}$ & $\mathbf{5}$ & $\mathbf{0}$ \\
\hline
\end{tabular}


Q7. How do you evaluate the effectiveness of periodic progress reports in managing and controlling the project?

The response for $\mathrm{Q} 7$ can be summarized in the following table.

\begin{tabular}{ccccccc}
\hline Sample & Don't Know & None & Weak & Good & Very Good & Exclnt. \\
\hline Public Owners & 0 & 1 & 8 & 15 & 1 & 0 \\
Private Owners & 0 & 3 & 8 & 3 & 1 & 0 \\
PM firms & 0 & 0 & 2 & 9 & 4 & 0 \\
Engineering firms & 1 & 1 & 6 & 6 & 1 & 0 \\
Contractors & 0 & 4 & 16 & 10 & 0 & 0 \\
Total & 1 & $\mathbf{9}$ & $\mathbf{4 0}$ & $\mathbf{4 3}$ & $\mathbf{7}$ & $\mathbf{0}$ \\
\hline
\end{tabular}

\subsection{Data Analysis \& Results}

This section reviews the actual analysis and results of the questionnaire survey for each participant group. The responses from the collected samples can be summarized in the following table:

The contracting parties need for progress reports to know the status of a project:

\begin{tabular}{|c|c|c|c|c|c|c|}
\hline \multirow[b]{2}{*}{ Q } & \multirow[b]{2}{*}{ Progress Reports } & \multicolumn{5}{|c|}{ Percentage of Needs } \\
\hline & & $\begin{array}{l}\text { Public } \\
\text { Owner }\end{array}$ & $\begin{array}{l}\text { Private } \\
\text { Owner }\end{array}$ & $\begin{array}{c}\text { PM } \\
\text { Firms }\end{array}$ & $\begin{array}{l}\text { Eng. } \\
\text { Firms }\end{array}$ & Contractor \\
\hline 1 & $\begin{array}{l}\text { Knowledge of project status } \\
\text { without progress reports }\end{array}$ & $96 \%$ & $73 \%$ & $100 \%$ & $100 \%$ & $87 \%$ \\
\hline \multicolumn{7}{|c|}{$\begin{array}{l}\text { The Percentage Average of all Contracting Parties need for a progress reports to know } \\
\text { the status of a project is } 91 \%\end{array}$} \\
\hline
\end{tabular}

The parties' acceptance to available progress reports:

\begin{tabular}{|c|c|c|c|c|c|c|}
\hline \multirow[b]{2}{*}{ Q } & \multirow[b]{2}{*}{ Progress Reports } & \multicolumn{5}{|c|}{ Percentage of Acceptance } \\
\hline & & $\begin{array}{l}\text { Public } \\
\text { Owner }\end{array}$ & $\begin{array}{l}\text { Private } \\
\text { Owner }\end{array}$ & $\begin{array}{c}\text { PM } \\
\text { Firms }\end{array}$ & $\begin{array}{l}\text { Eng. } \\
\text { Firms }\end{array}$ & Contractor \\
\hline 2 & A specific and effective monitoring system & $12 \%$ & $13 \%$ & $100 \%$ & $40 \%$ & $30 \%$ \\
\hline 3 & $\begin{array}{l}\text { The benefits of periodic progress reports } \\
\text { prepared by any of the contracting parties }\end{array}$ & $64 \%$ & $20 \%$ & $87 \%$ & $47 \%$ & $33 \%$ \\
\hline 4 & $\begin{array}{l}\text { The benefits of progress reports in } \\
\text { alerting against possible future claims }\end{array}$ & $32 \%$ & $27 \%$ & $73 \%$ & $33 \%$ & $17 \%$ \\
\hline 5 & $\begin{array}{l}\text { The accuracy of the Percent completion in } \\
\text { progress reports against the Actual percent }\end{array}$ & $28 \%$ & $20 \%$ & $73 \%$ & $40 \%$ & $13 \%$ \\
\hline 6 & $\begin{array}{l}\text { The impact of progress reports on limiting } \\
\text { problems and disputes }\end{array}$ & $28 \%$ & $20 \%$ & $47 \%$ & $13 \%$ & $17 \%$ \\
\hline 7 & Progress Report Effectiveness & $64 \%$ & $27 \%$ & $87 \%$ & $47 \%$ & $33 \%$ \\
\hline \multicolumn{2}{|r|}{$\begin{array}{l}\text { The Percentage Average of each Contracting } \\
\text { Parties Acceptance }\end{array}$} & $38 \%$ & $21 \%$ & $78 \%$ & $37 \%$ & $24 \%$ \\
\hline \multicolumn{7}{|c|}{ The Percentage Average of all Contracting Parties Acceptance } \\
\hline
\end{tabular}


It is clear from the previous responses shown in the table of ratios assigned to the parties to the contract and the difference in them and the agreement, the other times:

1) The Party that reports on the effectiveness of the periodic reports in particular is project management, and it does not have the authority to declare otherwise as the author of those reports.

2) While the views of the rest of the parties show that they are not benefiting from these reports, except for the representatives of the owners of the public sector, although their utilization rate is low.

3) The main reasons for not benefiting from these reports are the following:

- The magnitude of the reports.

- Difficulty obtaining specific information.

- The accuracy of the percentages of achievement contained therein compared to the actual rates of achievement.

As the selected sample represents the majority of contracting contracts in the State of Kuwait and based on the recognition of double the size of the benefit from the current periodic reports, we conclude that there is no specific system and effective follow-up projects.

\section{Conclusions}

With reference to the traditional periodic reports prepared to record the progress of the work, we find that they accept more than one interpretation, which means they can be interpreted differently by each party according to its background and technical expertise. From the analysis of the statements of the respondents to the research study, we find that there are general common problems. Perhaps the most important of all is the lack of the construction industry to have a simple and practical system that is easy to set up to determine the delay of the work of the project so that it can be applied, read, followed, understood and trusted by practically all concerned parties.

As a result, there was a need to find a simplified model that could be prepared by any of the contracting parties to follow up the delay in the progress of the project so that the same concept could be communicated to all contracting parties, including non-specialists in this field or the engineering field.

From the above results and data analysis, we conclude that there is a pressing need for a new models for periodic progress reports that are characterized by the following features: 1) the ease and speed of preparation, whether by program engineers or others at any moment; 2 ) the agreement of the parties on the vocabulary of this model, in a manner that cannot be interpreted or modified by a party without the knowledge of others; 3 ) easy, simple and concise reading of the vocabulary of the model; 4) accuracy of the model's information and not its magnitude; 5) include the financial and actual financial position of the project; and 6) easy to read report for non-engineers.

The standard progress report should be able for: 1) identify any time or financial 
deviations; 2) identify the culprit for these deviations; 3) identify the impact of these deviations on the progress of the project; 4) emphasize the role of project management in addressing these deviations as much as possible and within the capabilities of contracting parties; 5) emphasize that the role of project management is a neutral role between the contracting parties and not a lawyer for the owner; 6) provide the user with clear and concise details of the most important elements in the progress of project implementation; 7) know the likelihood of future claims that need to be resolved or started; and 8) adjust the percentage accuracy of completion.

This should prove useful to all project stakeholders and should minimize the likelihood of disputes and litigation.

\section{References}

[1] De Marco, A., Briccarello, D. and Rafele, C. (2009) Cost and Schedule Monitoring of Industrial Building Projects: Case Study. Journal of Construction Engineering and Management, 135, 853-862.

https://doi.org/10.1061/(ASCE)CO.1943-7862.0000055

[2] Navon, R. and Haskaya, I. (2006) Is Detailed Progress Monitoring Possible without Designated Manual Data Collection? Construction Management and Economics, 24, 1225-1229. https://doi.org/10.1080/01446190600999097 